\title{
Concerning Methods of the Transcultural Academic Writing
}

\author{
ロバートキャンベル
}

\section{シンポジウム講演記録}

国文学研究資料館館長のキャンベルでございま す。今日は与えられたテーマに寄せて国文学研究 資料館館長という立場ではなく、私自身の、自ら のそしい経験や感想、それからできれば最後に一 つ二つほど国際化について、試みたいと思ってお ります。今日のシンポジウムの第一セッションか ら第二セッションにかけて、いくつか通底してい るテーマがあると思いますけれども、論文を何語 で書くべきかということが一つのテーマというか、 課題として浮かび上がったように思います。沼野 先生が 2 年前に経験した気まずい沈黙、つまり優 れた論文であってもそれが英語で書かれていな ければ世界に存在しないと同然であると感じたこ と、それは私自身、日本語の書き手として感じた ことは何度もあるわけです。ただ一方では、何語 で書くかというよりも、論理構成であるとか、つ まり同じ優れた日本語の文献、研究業績というも のをそのまま他言語化させた時に、どこかそれが 論文としては十分なレベルに到達しないと見なさ れ、あるいは理解されないというところがありま す。私はどちらかというと、今後、日本の人文学 を他言語化させ、あるいは世界と日本の知をネッ トワーク化させ資源化していく上ではかなり大き な課題であり、あるいは思考のエリアとして少し 深掘りをして考えていくべきではないかと思いま す。そういう意味では、私も 20 年ほど前に、アメ リカ・インディアナ大学のある国際学会集会に招
かれ、私の専門とする江戸文学のパネルで、吉原 遊郭の中で作られた漢詩文学で取材した未紹介の 作品をいくつか紹介をし、英訳をしながらその意 味するところを紹介するような発表をさせていた だいたのですけれども、その後の懇親会の席で、 これはアメリカ人ではなく日本の名高い比較文学 者から言われたことは、とても忘れることができ ません。つまり、「キャンベル君が今日発表したこ とは素材としては大変面白い。まあ、言ってみれば、 あの炭鉱の中に入っていって素晴らしい原石をい ろいろと発掘していたわけだけれども、それを精 製し磨いて、研究として昇華していくのが我々比 較文学研究者であったり、あるいは他言語化させ た時にそれが初めて研究としてなる」ということ で、国文学的な手法そのものを第一次産業的な物 として、つまりマテリアルを発掘する役割だけを 担うものとしてとらえる眼差を向けておられるこ とを私は非常にはっきりと感じて、その時すぐに、 反駁することはできなかったわけです。私が反論・ 反駁することができなかった理由としては、国文 学研究では実証を重んじるものであります。実証 を重んじると同時に、あるいはその一環としてマ テリアルを非常に重視するわけであります。それ は歴史的な背景を考えますと当然のことでして、 私が18世紀から 19世紀にかけて書かれた、例え ばウォルター・スコットの小説、ジェイン・オー スティンの小説を、例えば原本が手の中にあれば 東京の地下鉄に乗ったところでもどこでもそれを 
十全に解読・読解することはできるけれども、曲 亭馬琴の小説の原本がもしあるとしても、それは 恐らく、私を含めてほとんどの人が、地下鉄の中 でつまり素手でそのまま読解をすることは、大変 困難なところであります。日本の近代そのものを 成立させる様々な条件の中で、明治 10 年代から 20 年代にかけて、書記言語としての日本語の文法的 な、そして書記としての、オーソグラフィーに大 きな変化がもたらされ、その断絶の向こう側に現 代のほとんどの日本語話者が立っているというこ とであります。つまり、60万あるいは70万タイト ルと言われる日本の古典籍、明治より前に作られ た書物はほんの一部しか翻読・翻字されておらず、 その中に、見方と使い方によっては非常に豊穣な 素材として横たわっている。言い方を変えれば、 ほとんど手付かずに近い形で、限られた能力を 持った限られた人しかそこにアクセスキーを持っ ていない、ということがまずあります。国文学の 研究に入っていく、最初の入り口としては、その ような書記体、崩し字を読み、漢文を読み、候文 が読解でき、戯作文も理解し、そこに書かれてい る、現在と大きく異なる様々な事柄の中に入って いって、できる限り同時代の人々と同じ地平に立 つ、ということが求められるわけです。つまり国 文学の研究者たちというのは、ある意味では翻訳 を、現代とかつての文化、言語文化というものを トランスフォームしていく、トランスクライブし ていく、基本的な作業というものがまずあります。 そこから研究そのものの佇まい、あるいは期待さ れることが、同時代の欧米文学とは最初から大き く異なるところがあると言えると思います。その ような実証性、安直には言いたくありませんけれ ども、帰納的推論と言いましょうか、いくつかの 具体的な事象を並べてそこから結論へと結びつい ていく、そういう方法、基本的な思考というものが、 歴史的な背景と哚く結びついたところがある、と
いうことを、まず念頭に置かなければなりません。 窪䄇先生が留学時代に、大相撲の横綱級のエビデ ンスを最後まで取っておくなとか、結論を先に言 えと指導されたというようなことは、思考法とし ていわゆる国文学的手法とも相性が良いものだと 言えます。

さて、私が今日の演題として掲げました英語 のタイトルを日本語で翻訳をすると、「文化を超 えた学術的論述の方法について」という翻訳がで きるかと思います。日本語としては順当な言い方 だと思いますし、なんとなく日本語の論文ぽい 響きもあるかもしれませんけれども、実は少し仕 掛けがあります。このタイトルは、私が英語で 何か発表する、あるいは論文を掲載する時に決 して使うタイトルではありません。これは不適 格なタイトルとして、私は敢えて今日の演題と して揭げたわけです。“(Concerning Methods of the) Transcultural Academic Writing” は、語彙が明瞭な 名詞として並んでいるわけですけれども、この (Concerning Methods of)、方法であるとか、何々 を巡ってとか、何々に関して、については、実は 日本語ローカルな、一つの論文、あるいは著述を 書くときによく使われる言葉です。ここで、英語 圈で歴史研究として発表された、二つの大変すぐ れた著書を紹介したいと思います。二つとも、ア フリカ系アメリカ人の歴史からアメリカの市民社 会の歴史を捉え直した優れた著書ですが、一つは BIRTHRIGHT CITIZENS 『生得市民権』というそ のままのテーマが書かれています。もう一つは、 ACCOUNTING FOR SLAVERY『奴隷制度の経理 学』という著作ですが、これには実は、ちょっと した掛詞といいますか、駄酒落が込められていま す。ACCOUNTINGというのはもちろん経理学・ 会計学のことではありますけれども、forが付くこ とによって、「責任の在処」、この奴隷制度の責任 
というものは、今日的な問題としてどこにあり、 その沿革を描き、現在の社会につなげていくとい うような意味が、タイトルの中に表れてきます。 このように、思考のパラダイムそのものが異なる ということは、扔そらくこれは間違いないところ でして、それをどういうふうにすり合わせていく かということが、大きなテーマになるように思い ます。

さて、ここから残された時間で、私が 2 年ほど 前にカリフォルニア大学バークレー校で英語で 行った発表、これはちょっと不十分なものだった わけですけれど、そこで得た経験と確信について、 少し話をしたいと思います。『衆楽雅藻』という書 物は明治3年（1870）に、今の岡山県にあった津 山藩の最後の大名、松平慶倫が、自費によって出 版させて、私家版として配付したものです。活字 にもなっていませんし、ましてや英語で発表され たわけではありません。私がたまたまこれをある 古書店で見いだして、手元に置いている、自分の ところの書物です。その書物からここは一つの例 として、明治初期に公共圈というものが、表象文 化の中でどのように発生したのか、どのような蹉 跌がその中で見て取れるのか、という話をしまし た。要するに、一つの書物に即して入っていくわ けです。マテリアル至上主義と言いましたけれど も、この書物を、例えば口絵・挿絵をずっと見て いきますと、江戸時代より以前に、曲水の宴とい う、文人たちが集まって詩を詠じ合う場というも のがあるわけですけれども、廃藩置県と同じ年に、 最後の大名が自分の庭園を領民に開放をして、文 人たち、つまり家臣たちの武家階級が文化を演じ ているところを見せる。そしてそこから一つの公 共圈を形成させようとする。折表的な興味深いこ とがそこで行われていくわけですけれども、これ は文字だけではなくて、明治初期に描かれている
いわゆる文人画という表現態を用いて挿絵による 補足説明がなされており、ここから新たな、やが ては衆議院制度政治というものにも繋がっていく、 公共圈の生成ということに繋がっていきます。18 世紀以来のロンドンのロイヤルアカデミーのよう に、多くの不特定多数の人たちが集まり、詩や絵 を見て、見守り、口論をする。議論をすることによっ て、公共というもの、公共の場というものを作っ ていく、ということが描かれています。これはほ とんど漢文で、たいへん細かいものまで書かれて いるわけですけれども、それを英訳して一つ一つ 説明をしていく中で、

"Some while ago, though, our Lord permitted both samurai and common folk to enter the grounds to view them."

という、それまでは統治層の武家が占有する空 間が、どのように市民、ここでは「士」に「民」と 書いていますけれども、これはやがて明治 20 年代 に「市」に「民」、CITIZENという言葉に置き換え る、読み換えられるものですけれども、ここで侍 と庶民という対比として空間を開いていく、とい うことが漢文の中で書かれているわけです。一方 では、日記などの歴史資料が津山にたくさんあり まして、大変具体的な記述がなされていて、どう いうふうにこの行事を、大名と家臣団が実際に行っ ていたか、振る舞いまでがわかりました。欧米の 人文学の中で、今日、最も重要視されていること は、パブリックヒューマニティーズという分野だ と思います。今、ここにイェール大学のピーター・ ブルックスの HUMANITIES AND PUBLIC LIFE という、5年ほど前に出版された本があります。 Public、公共の中で人文学を生成し作っていくと いうことだけではなくて、Public Engagement、ど ういうふうに人々の文化へのアクセス、様々な不 均衡というものを今日的なテーマとしてつなげて、 実証的な歴史研究とつなげて作っていくかという 
ことが論じられているわけです。この衆楽園とい う空間が、今も津山市に残っておりまして、ほぼ 当時の景観をとどめています。4年ほど前ですけ れども、市民とともに、このイベントそのものを 再現して、衆楽園で曲水の宴を行いました。これは、 そこで行われた、日本の江戸時代から近代への一 つの橋渡しになる、それを象徴するようなものと して、CITIZEN SCIENCEですね、木部先生が先 ほどおっしゃったように、地域の人々を研究であ るとか素材であるとか、そういった人たちをリソー スの中にどういうふうにつなげていくか、という ことを実現する一つの試みとして、考えたイベン トだったわけです。

私の時間は既に超過しておりますのでこの辺り で私の話をおしまいにしたいと思います。

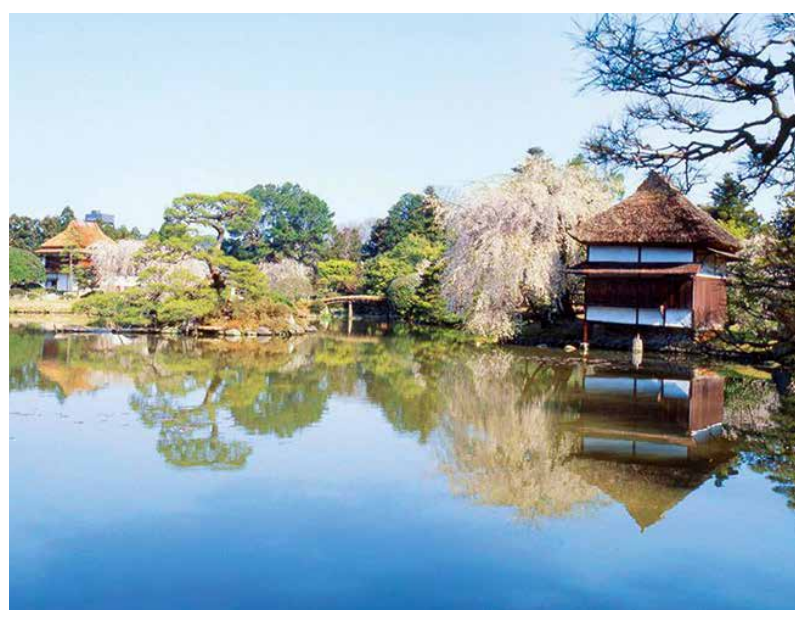

衆楽園（旧津山藩別邸庭園）

写真提供：公益社団法人津山市観光協会

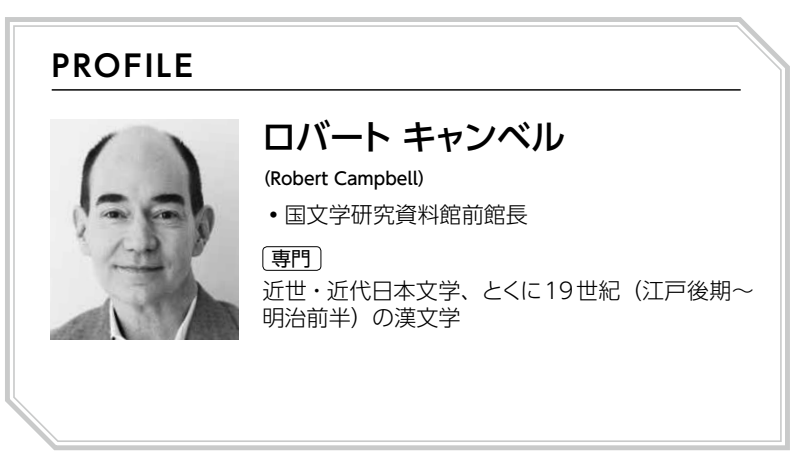

